Article

\title{
The Feeding Rate of Predatory Mites on Life Stages of Bemisia tabaci Mediterranean Species
}

\author{
Andrew G. S. Cuthbertson \\ The Food and Environment Research Agency, Sand Hutton, York YO41 1LZ, UK; \\ E-Mail: andrew.cuthbertson@fera.gsi.gov.uk; Tel.: +44-0-1904-462201; Fax: +44-0-1904-462111
}

Received: 12 June 2014; in revised form: 2 July 2014 / Accepted: 17 July 2014 /

Published: 22 July 2014

\begin{abstract}
The sweetpotato whitefly Bemisia tabaci (Gennadius) (Hemiptera: Aleyrodidae) continues to be a serious threat to crops worldwide. The UK holds Protected Zone status against this pest and, as a result, $B$. tabaci entering on plant material is subjected to a policy of eradication. There has recently been a shift from Middle East-Asia Minor 1 to the more chemical resistant Mediterranean species entering the UK. Predatory mites (Amblyseius swirskii, Transeius montdorensis and Typhlodromalus limonicus) were screened for their impact upon various lifestages of $B$. tabaci Mediterranean species. Approximately $30 \%$ of eggs were fed upon by $A$. swirskii following a 5 day period. Feeding rates slightly decreased for all mite species when feeding on first instar life-stages $(27 \%, 24 \%, 16 \%$ respectively) and significantly decreased when feeding on second instars (8.5\%, 8.5\%, 8.7\% respectively). Combining the two mite species (A. swirskii and T. montdorensis) increased mortality of Bemisia eggs to $36 \%$. The potential of incorporating the mites into existing control strategies for $B$. tabaci is discussed.
\end{abstract}

Keywords: Bemisia tabaci; predatory mite; Integrated Pest Management

\section{Introduction}

The whitefly Bemisia tabaci (Hemiptera: Aleyrodidae) is an obligate phloem-feeding pest, which is globally distributed, being found in all continents except Antarctica [1]. It affects more than 600 recognized plant hosts of both agricultural and horticultural crops and also ornamental plants [2-4]. Bemisia tabaci has been considered as one of the most destructive pests in tropical, subtropical and temperate zones $[5,6]$. Damage can be caused directly by feeding on phloem sap or indirectly by the large 
amounts of honeydew produced so lowering photosynthesis. Bemisia tabaci is also a vector of many plant viruses $[7,8]$.

The pest status of $B$. tabaci insects is complicated by the recognition of 11 well-defined genetic biotypes and at least 24 morphocryptic species which are morphologically identical but distinguishable at the molecular level [6,9]. Through the comparison of mitochondrial cytochrome oxidase 1 (mtCO1) these 11 genetic biotypes can be mapped to Asia 1 (M, H); Australia/Indonesia, Australia (AN); China (Non B) Asia II (G, K, P); Asia II India, Italy (T); Sub-Saharan Africa non-silverleafing (E,S); New World (A, D); Africa/Middle East/Asia Minor (Q, J, L, Sub-Saharan Africa silverleafing, B, B2 and MS) and Uganda [6]. It is the Middle East-Asia Minor 1 and Mediterranean species that are the two most widely distributed, and as a result, best known species. These two species present the greatest threat to glasshouse crops worldwide [10]. The damaging Middle East-Asia Minor 1 (Biotype B) is described as an aggressive coloniser and is an effective vector of many viruses, whereas the Mediterranean species (Biotype Q) characteristically shows strong resistance to novel insecticides [11,12].

In relation to the UK, $B$. tabaci has been intercepted annually on imported plant material since 1987 [13]. The primary concern for the UK is that the whitefly imported on ornamental plants such as poinsettia (Euphorbia pulcherrima) can transfer and infect glasshouse salad crops such as tomato and cucumber with Tomato yellow leaf curl virus (TYLCV), Tomato yellow leaf curl Sardinia virus (TYLCSV) and Cucurbit yellow stunting disorder virus (CYSDV) all of which are not currently present in the UK. To-date, although there are many interceptions of B. tabaci in the UK, the species and its associated viruses have not become established; to this end the UK continues to hold "Protected Zone" status against this pest with statutory action aimed at eradication taken whenever it is found $[13,14]$. A recent study by Powell et al. [15] determined that there was a shift from Middle East-Asia Minor 1 to Mediterranean species entering the UK. Therefore, there is a need for various control options, including predatory mites, to be investigated against this Bemisia species. The aim of the current study was to determine the feeding rate of various commercially available predatory mites within the UK on B. tabaci Mediterranean in order to determine their potential to be incorporated into existing eradication strategies.

\section{Experimental}

\subsection{Source of Insects}

Specimens of $B$. tabaci Mediterranean were obtained from an outbreak situation in the UK during autumn 2012. They were then under quarantine conditions cultured in Perspex ${ }^{\circledR}$ cages $(60 \times 60 \times 80 \mathrm{~cm})$ on poinsettia plants following the method of Cuthbertson et al. [16]. Commercially available predatory mite species Amblyseius swirskii, Transeius montdorensis (still marketed in the UK as Amblyseius montdorensis) and Typhlodromalus limonicus were supplied by Syngenta Bioline, UK.

\subsection{Feeding Trails}

Following the method of Cuthbertson et al. [17], a single predatory mite was placed on poinsettia leaf discs, together with $10 \mathrm{~B}$. tabaci eggs as prey. The eggs were transferred onto the leaf disc using a 
fine camel hairbrush. The leaf discs, eggs and mites were then contained in an experimental arena [18]. This briefly consisted of two acrylic plates sandwiching a filter paper wick that fed a square of blotting paper upon which was placed an excised cucumber leaf covered by a second (1 cm thick) acrylic sheet with a $5 \mathrm{~cm}$ diameter aperture drilled in it. The arenas were incubated in a controlled environment cabinet at $21^{\circ} \mathrm{C}$ (average UK glasshouse temperature [19]), 65\% relative humidity (r.h.), and 16:8 Light:Dark. The number of eggs that were attacked or had clear symptoms of feeding damage were recorded after five days to determine consumption rates. The experiment was replicated 20 times. The controls consisted of an identical experimental procedure to those used for each treatment, with the exception that a predatory mite was not placed in the experimental arenas.

The above procedure was repeated for first and second instar Bemisia life stages and for each mite species separately. A trial was also undertaken combining an individual A. swirskii and T. montdorensis together to investigate their combined predatory potential.

\subsection{Data Analysis}

Data was analysed where appropriate. Assuming normality and constant variance, analysis of variance (ANOVA) was used to test any significant difference between different treatments (mite species) and the control.

\section{Results and Discussion}

Phytoseiid mites are known to feed on phytophagous insects such as thrips [20] and whiteflies [21]. In particular, A. swirskii (Figure 1) has been shown to offer potential to be a major control agent against $B$. tabaci in several situations [22-25].

Figure 1. The predatory mite, Amblyseius swirskii (UK Crown Copyright ${ }^{\odot}$ ).

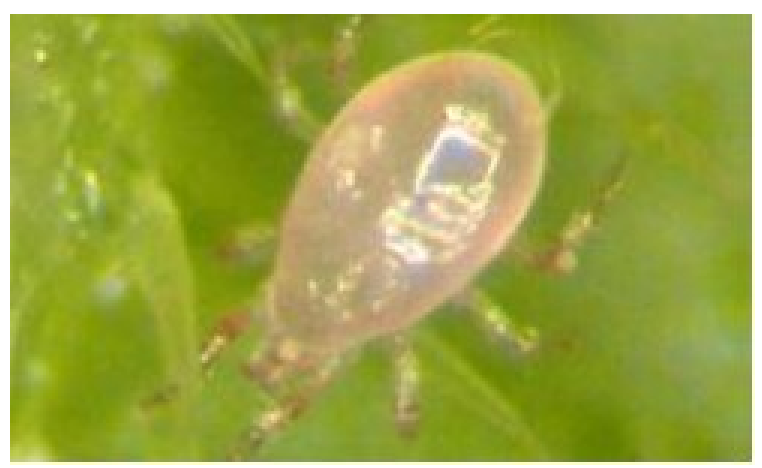

Investigating the predation rates of the three predatory mite species (A. swirskii, T. montdorensis, T. limonicus) has proven all three readily feed upon the early life-stages of Bemisia. Approximately $30 \%$ of eggs were fed upon by $A$. swirskii following the 5 day period (Figure 2). There was no significant difference in egg consumption among the individual mites $(p>0.05)$. However, combining T. montdorensis and A. swirskii significantly increased egg consumption $(p<0.01)$. Predation percentages slightly decreased for all individual mite species when feeding on first instar life-stages $(27 \%, 24 \%, 16 \%$ respectively) and significantly $(p<0.001)$ decreased when feeding on second instars $(8.5 \%, 8.5 \%, 8.7 \%$ respectively). 
In many cases, predatory mites have been successfully applied in the control of thrips but until relatively recent years no attempt has been made to use them in whitefly control [21]. Previous studies have shown the potential of predatory mites to be important components of integrated pest management strategies against the non-indigenous pest species Thrips palmi in the UK [17]. The predatory mites currently investigated show equal potential in regards to their efficacy against B. tabaci Mediterranean. Predatory mites are known to be most effective against egg and early instars of whiteflies [26], simply as adult whiteflies will fly away from an attacking predatory mite except during emergence from the last nymphal stage [27]. Combining the two species of mites gave some increase in mortality of all life-stages of $B$. tabaci tested against.

The predatory mites investigated are also known to show various levels of compatibility with various chemical insecticides [17]. They therefore offer potential to be incorporated into existing eradication strategies against $B$. tabaci in the UK.

Figure 2. The impact of predatory mites against Bemisia tabaci Mediterranean lifestages. Mortality assessed following 5 days. AS-Amblyseius swirskii; TM-Transeius montdorensis; TL-Typhlodromalus limonicus.

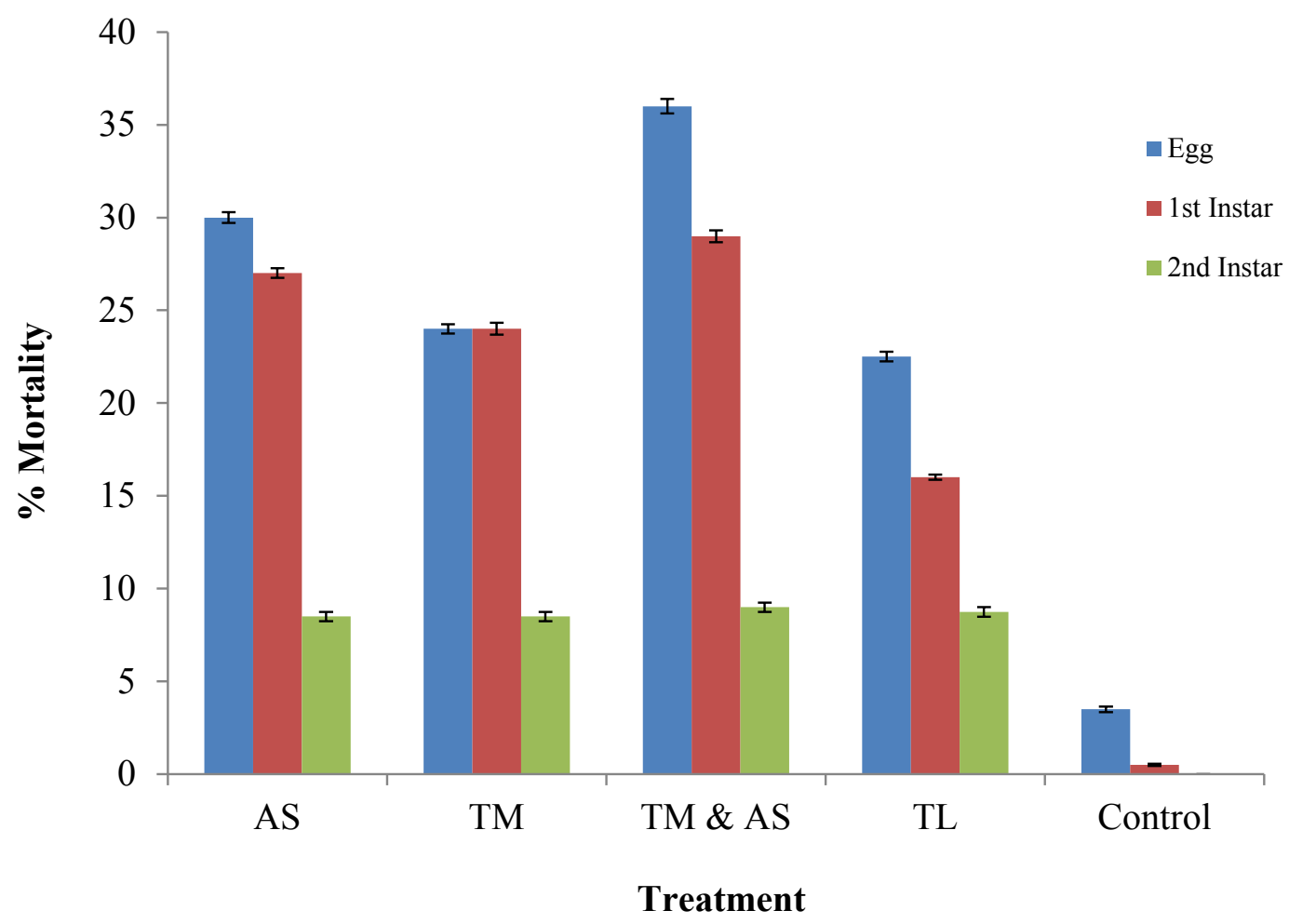

\section{Conclusions}

Bemisia tabaci remains a severe threat to UK horticulture [13]. The continuing interception of insecticide resistance $B$. tabaci Mediterranean poses a real challenge in regards to maintaining the UK's Protective Zone status. The mites investigated are known to have compatibility with several chemical insecticides [17] and so offer much potential to be incorporated into existing eradication strategies. 


\section{Acknowledgments}

The work was funded by the Department of Environment Food and Rural Affairs (Defra), UK. The mites were supplied by Syngenta Bioline UK.

\section{Conflicts of Interest}

The author declares no conflict of interest.

\section{References}

1. De Barro, P.J.; Hart, P.J. Mating interactions between two biotypes of the whitefly, Bemisia tabaci (Hemiptera: Aleyrodidae) in Australia. Bull. Entomol. Res. 2000, 90, 103-112.

2. Cock, M.J.N. Bemisia Tabaci, a Literature Survey: On the Cotton Whitefly with an Annotated Bibliography; FAO/CAB International Institute of Biologica-1 Control: Ascot, UK, 1986; p. 21.

3. Oliveira, M.R.V.; Henneberry, T.J.; Anderson, P. History, current status and collaborative research projects for Bemisia tabaci. Crop Prot. 2001, 20, 709-723.

4. Gelman, D.B.; Blackburn, M.B.; Hu, J.S. Identification of the molting hormone of the sweet potato (Bemisia tabaci) and greenhouse (Trialeurodes vaporariorum) whitefly. J. Insect Physiol. 2005, 51, 47-53.

5. Dalton, R. Whitefly infestations: The Christmas invasion. Nature 2006, 443, 898-900.

6. De Barro, P.J.; Liu, S.S.; Boykin, L.M.; Dinsdale, A.B. Bemisia tabaci: A statement of species status. Annu. Rev. Entomol. 2011, 56, 1-19.

7. Alegbejo, M.D. Whitefly transmitted plant viruses in Nigeria. J. Sustain. Agric. 2000, 17, 99-109.

8. Simón, B.; Cenis, J.L.; Demichelis, S.; Rapisarda, C.; Cacigli, P.; Bosco, D. Survey of Bemisa tabaci (Hemiptera: Aleyrodidae) biotypes in Italy with the description of a new biotype (T) from Euphorbia characias. Bull. Entomol. Res. 2003, 93, 259-264.

9. Dinsdale, A.; Cook, L.; Riginos, C.; Buckley, Y.M.; de Barro, P. Refined global analysis of bemisia tabaci (Hemiptera: Sternorrhyncha: Aleyrodoidea: Aleyrodidae) mitochondrial cytochrome oxidase 1 to identify species level genetic boundaries. Annu. Rev. Entomol. Soc. Am. 2010, 103, 196-208.

10. Bethke, J.A.; Byrne, F.J.; Hodges, G.S.; McKenzie, C.L.; Shatters, R.G. First record of the Q biotype of the sweetpotato whitefly, Bemisia tabaci, in Guatemala. Phytoparasitica 2009, 37, 61-64.

11. Jones, C.M.; Gorman, K.; Denholm, I.; Williamson, M.S. High-throughput allelic discrimination of B and Q biotypes of the whitefly, Bemisia tabaci, using TaqMan allele-selective PCR. Pest Manag. Sci. 2008, 64, 12-15.

12. McKenzie, C.I.; Hodges, G.; Osborne, L.; Byrne, F.J.; Shatters, R.G. Distribution of Bemisia tabaci (Hemiptera: Aleyrodidae) Biotypes in Florida-Investigating the Q Invasion. Hortic. Entomol. 2009, 102, 670-676.

13. Cuthbertson, A.G.S. Update on the status of Bemisia tabaci in the UK and the use of entomopathogenic fungi within eradication programmes. Insects 2013, 4, 198-205.

14. Cheek, S.; Macdonald, O. Statutory controls to prevent the establishment of Bemisia tabaci in the United Kingdom. Pestic. Sci. 1994, 42, 135-142. 
15. Powell, M.E.; Cuthbertson, A.G.S.; Bell, H.A.; Boonham, N.; Morris, J.; Northing, P. First record of the Q Biotype of the sweetpotato whitefly, Bemisia tabaci, intercepted in the UK. Eur. J. Plant Pathol. 2012, 133, 797-801.

16. Cuthbertson, A.G.S.; Head, J.; Walters, K.F.A.; Gregory, S.A. The efficacy of the entomopathogenic nematode, Steinernema feltiae, against the immature stages of Bemisia tabaci. J. Invertebr. Pathol. 2003, 83, 267-269.

17. Cuthbertson, A.G.S.; Mathers, J.J.; Croft, P.; Nattriss, N.; Blackburn, L.F.; Luo, W.; Northing, P.; Murai, T.; Jacobson, R.J.; Walters, K.F.A. Prey consumption rates and compatibility with pesticides of four predatory mites from the family Phytoseiidae attacking Thrips palmi Karny (Thysanoptera: Thripidae). Pest Manag. Sci. 2012, 68, 1289-1295.

18. Tashiro, H. Self-watering acrylic cages for confining insects and mites on detached leaves. J. Econ. Entomol. 1967, 60, 354-356.

19. Cuthbertson, A.G.S.; Mathers, J.J.; Blackburn, L.F.; Korycinska, A.; Powell, M.E.; Luo, W.; Jacobson, R.J.; Northing, P. Population development of Tuta absoluta (Meyrick) (Lepidoptera: Gelechiidae) under simulated UK glasshouse conditions. Insects 2012, 4, 185-197.

20. Messelink, G.J.; van Steenpaal, S.E.F.; Ramakers, P.M.J. Evaluation of phytoseiid predators for control of western flower thrips on greenhouse cucumber. Biocontrol 2006, 51, 753-768.

21. Nomikou, M.; Sabelis, M.W.; Janssen, A. Pollen subsidies promote whitefly control through the numerical response of predatory mites. Biocontrol 2010, 55, 253-260.

22. Calvo, F.J.; Bolckmans, K.; Belda, J.E. Control of Bemisia tabaci and Frankliniella occidentalis in cucumber by Amblyseius swirskii. Biocontrol 2011, 56, 185-192.

23. Xiao, Y.-F.; Avery, P.; Chen, J.-J.; McKenzie, C.; Osborne, L. Ornamental pepper as banker plants for establishment of Amblyseius swirskii (Acari: Phytoseiidae) for biological control of multiple pests in greenhouse vegetable production. Biol. Control 2012, 63, 279-286.

24. Onzo, A.; Zannou, I.D.; Adjibade, O.A.J.D.; Broutani, S.; Hanna, R. Potentialités de l'acarien prédateur Amblyseius swirskii (Athias-Henriot) (Acari: Phytoséiidae) dans la lutte biologique contre la mouche blanche Bemisia tabaci (Genn.), vecteur de la mosaïque du manioc en Afrique. Int. J. Biol. Chem. Sci. 2012, 6, 5085-5102.

25. Calvo, F.J.; Bolckmans, K.; Belda, J.E. Biological control-based IPM in sweet pepper glasshouses using Amblyseius swirskii (Acri: Phytoseiidae). Biocontrol Sci. Technol. 2012, 22, 1398-1416.

26. Nomikou, M.; Janssen, A.; Schraag, R.; Sabelis, M.W. Vulnerability of Bemisia tabaci immatures to phytoseiid predators: Consequences for oviposition and influence of alternative food. Entomol. Exp. Appl. 2004, 110, 95-102.

27. Nomikou, M.; Janssen, A.; Schraag, R.; Sabelis, M.W. Phytoseiid predators suppress populations of Bemisia tabaci on cucumber plants with alternative food. Exp. App. Acarol. 2002, 27, 57-68.

(C) 2014 by the authors; licensee MDPI, Basel, Switzerland. This article is an open access article distributed under the terms and conditions of the Creative Commons Attribution license (http://creativecommons.org/licenses/by/3.0/). 